Journal of Applied Veterinary Sciences, 6 (4): 51 -57 (October, 2021).

ISSN: Online: 2090-3308, Print: 1687-4072

Journal homepage : https://javs.journals.ekb.eg

\title{
Plumage Color Influence on Immune Response and Severity of Fowlpox in The Progeny of Inbred Isa White Chickens
}

\author{
Bala Ningi Umar", Jibril Adamu, and Haruna Makonjuola Kazeem \\ Virology and Immunology Unit, Department of Veterinary Microbiology, Faculty of Veterinary Medicine, \\ Ahmadu Bello University, Zaria, Nigeria. \\ *Corresponding Author, Bala Ningi Umar, E-Mail: umarningi5@gmail.com
}

\begin{abstract}
There is limited information regarding chicken's inter and intra-breed resistance to the fowlpox virus (FWPV). Incidentally, it was observed during a natural fowlpox outbreak in a flock of inbred Isa White chickens having different plumage colors that those with predominantly white plumage were most severely affected. Thus, this study assessed the effects of plumage color in progenies of the affected chickens on immune response and severity of fowlpox virus infection. Thirty each of white and colored chickens were selected from the same hatch and challenged experimentally with a field fowlpox virus. Fifteen chickens from each plumage group were vaccinated against fowlpox prior to the challenge while the remaining unvaccinated half were infected with the field virus. Vaccine 'takes' diameters, discrete fowlpox lesions and FWPV antibody titer were evaluated. The highest mean vaccine 'takes' in white $(9.95 \pm 0.34 \mathrm{~mm})$ and colored $(10.74 \pm 0.41 \mathrm{~mm})$ chickens were observed on day-7 postvaccination. White chickens had lower mean antibodies to fowlpox virus pre- and post-vaccination $(21.83 \pm 3.32$ and $41.61 \pm 6.16 \mathrm{ng} / \mathrm{L})$ than colored chickens $(26.89 \pm 5.47$ and $53.25 \pm 7.26 \mathrm{ng} / \mathrm{L})$; however, the difference was not statistically significant $(p>0.05)$. In contrast, mean fowlpox lesions count differed significantly $(\mathrm{p}<0.05)$ between white $(4.00 \pm 0.56)$ and colored $(2.0 \pm 0.35)$ chickens. Immune responses and severity of fowlpox are likely influenced by plumage color in Isa White breed of chickens.
\end{abstract}

Keywords: Fowlpox, Humoral immunity, Resistance, Susceptibility, Virology.

\author{
Original Article: \\ DOI:https://dx.doi.org/10.21608/javs \\ . $\mathbf{2 0 2 1 . 8 8 5 7 4 . 1 0 9 7}$
}

Received :01 August, 2021.

Accepted :12 September, 2021.

Published in October, 2021.

This is an open access article under the term the Creative Commons Attribution 4.0 (CC-B International License . To view a copy of tl license, visit:

http://creativecommons.org/licenses/by/4.0/

J. Appl. Vet. Sci., 6(4): $51-57$.

\section{INTRODUCTION}

Fowlpox is a contagious viral disease of chickens and turkeys caused by the fowlpox virus (FWPV). The disease has two well recognized forms; the cutaneous (dry) form characterized by multifocal lesions of skin particularly around the eyelids, combs, wattle and thigh with low mortality, and the wet form characterized by diphtheritic lesions in digestive and respiratory tracts of birds causing sneezing, dyspnea and relatively high mortality (Tripathy and Reed, 2008; MacLachlan and Dubovi, 2017; Tripathy and Reed, 2020). Chickens may occasionally develop a mixed form, and a third rare systemic form affecting the entire tissues of birds has also been reported (VanRiper and Forrestor, 2007).

Fowlpox, an endemic disease in tropical and subtropical countries (Adene and Fatumbi, 2004;
Beytut and Haligur, 2007; OIE, 2016), is one of the most economically important poultry diseases causing a drop in egg production, reduced growth rate in young birds and death (Tripathy and Reed, 2020). It has been ranked as the third most important cause of death in Nigerian indigenous chickens (Abdu et al., 1992). Despite its alarming prevalence, detailed disease epidemiology has not been exploited (Meseko et al., 2012). In high-density, multiple-age farms, the disease may persist for long periods of time despite preventive vaccinations (Ferreira et al., 2018; Sarma et al., 2019). A number of recurrent outbreaks in vaccinated flocks have been reported globally (Odoya $\boldsymbol{e t}$ al., 2006; Okwor et al., 2014; Ferreira et al., 2018).

Fowlpox virus is extremely resistant to desiccation; it can survive within scab for a long period under different adverse environmental conditions (Srinivasan et al., 2001). The virus is reported to be 
pathogenic in chickens of all ages, sexes and breeds (Idris et al., 20018). Maclachlan and Dubovi (2017) speculated that "under natural conditions, there may be breed differences in susceptibility to fowlpox; chickens with large combs appear to be more affected than those with small combs." However, there is a paucity of information regarding inter and intra-breed levels of susceptibility as well as resistance to fowlpox in chickens. Hence, much research is needed in order to improve or develop newer breeds that are resistant to the disease. The present study was based on an observation following a natural fowlpox outbreak that chickens with predominant white feathers were most severely affected in a flock of inbred Isa White chickens. Progenies from the affected flock were challenged experimentally to assess the possible impact of plumage color on immune response and severity of fowlpox in chickens.

\section{MATERIALS AND METHODS}

\section{Ethical Consideration:}

The care for chickens used in this study was with professional standards as approved by the Ahmadu Bello University Committee on Animal Use and Care (ABUCAUC/2019/11).

\section{Experimental Chickens:}

Embryonated chicken eggs (ECE) weighing 45 to $50 \mathrm{~g}$ from healthy inbred Isa White breeder hens, sourced from Virology Unit, Department of Veterinary Microbiology, ABU Zaria-Nigeria, were used for the study. The eggs were hatched using an egg incubator (Brinsea Ova easy 380 , USA) at $37.5^{\circ} \mathrm{C}$. The chicks were fed twice daily using commercial poultry feed (Hybrid Feeds Ltd. Kaduna, Nigeria) and water was provided ad-libitum.

\section{Fowlpox Virus Vaccine and Antigen:}

A commercial 1,000 dose live attenuated fowlpox vaccine $\left(\mathrm{ABIC}^{\circledR}\right.$ Biological Laboratories Ltd. Israel, lot no. 20511046A) was used in this study. Fowlpox virus antigen was prepared from the infected chorioallantoic membrane (CAM) in accordance with OIE (2016) Guidelines. Briefly, eight local field outbreaks of fowlpox were identified, scabs were then collected and 20\% homogenate was prepared using antibiotics containing normal saline as a diluent. This was followed by two cycles of freezing and thawing, centrifugation and inoculation of supernatants onto the CAM of 10-day-old ECE as described by Gilhare (2012). Afterward, the infected CAMs with characteristic pock lesions were subjected to the same procedure as described for scabs to obtain the supernatant used as FWPV antigen for the challenge.

\section{Experimental Design:}

A total of 60 chickens comprising 30 each of white and colored (black, brown-black and mottled) were used for the study. The chickens were randomly assigned into four groups of 15 each based on their plumage colors as groups A, B, C and D. Groups A and $\mathrm{C}$ had white plumage while $\mathrm{B}$ and $\mathrm{D}$ were colored. Groups A and B were vaccinated at 8-week of age with $0.01 \mathrm{~mL}$ of live attenuated fowlpox vaccine via the right wing-web and later challenged with $0.1 \mathrm{~mL}$ of field FWPV isolate at 3-week post vaccination via the left wing-web site. Groups C and D were infected at 11 -week of age without prior vaccination.

\section{Sample Collection:}

The Vaccinated chickens (groups A and B) were examined for the presence and size of vaccine "takes" at the site of inoculation (from $5^{\text {th }}$ to $10^{\text {th }}$-day post-vaccination) using a Vernier caliper. Scab or swelling at the site of vaccine application was considered a positive reaction (takes). The presence and number of discrete fowlpox lesions were evaluated on day 18 and day 22 post-challenge. The average of the two readings for each chicken was considered as the number of lesions per bird.

Blood was collected into sterile plain vacutainer tubes pre-vaccination, 3-weeks postvaccination, and 3-weeks post-challenge in groups $\mathrm{A}$ and $\mathrm{B}$, while for groups $\mathrm{C}$ and $\mathrm{D}$ pre-infection and 3weeks post-infection. Sera were harvested from all the collected blood samples and used for FWPV antibody quantification using indirect enzyme-linked immunosorbent assay (ELISA) following the manufacturer's instruction (KTE220001, Abbkine, Inc, China).

\section{Data Analyses}

Data were analyzed using SPSS version 16.0 statistical software. Data were expressed as mean \pm standard error of mean (mean \pm SEM), subjected to statistical analyses using Independent t-test (vaccine takes diameters and FWPV antibody titers) and Mann Whitney U-test (fowlpox lesions count). Values of $\mathrm{p}$ $<0.05$ were considered significant.

\section{RESULTS}

\section{Isolation and Propagation of Field Fowlpox Virus Isolates:}

The infected CAMs revealed hemorrhages, edema, and generalized thickening with opaque-white pock lesions of about 3 to $5 \mathrm{~mm}$ in diameter at first passage (Plate I). More severe pock lesions were seen following three repeated passages (Plate II). There was high embryo mortality (30\%) in inoculated eggs with a foul odor. 


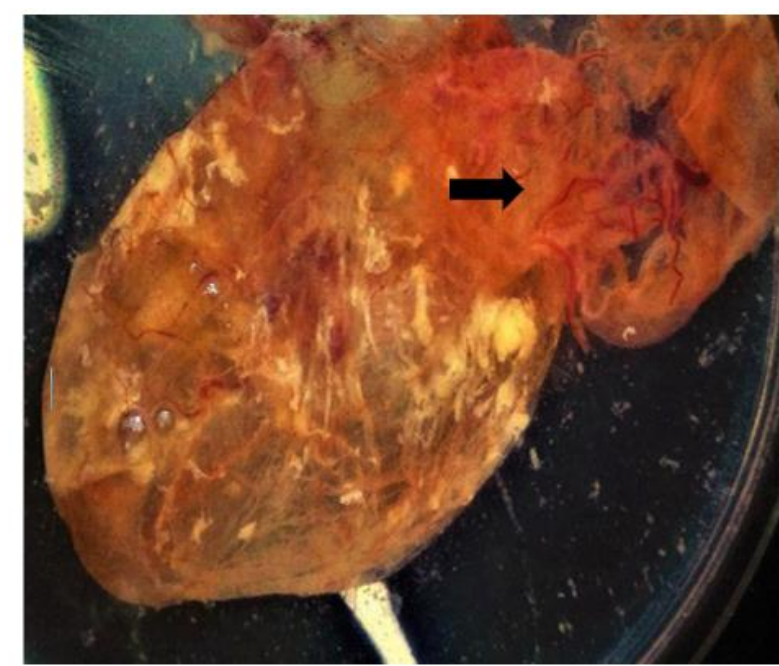

Plate I: Edematous \& hemorrhagic (black arrows) chorioallantoic membrane inoculated with a field fowlpox virus isolate at first passage.

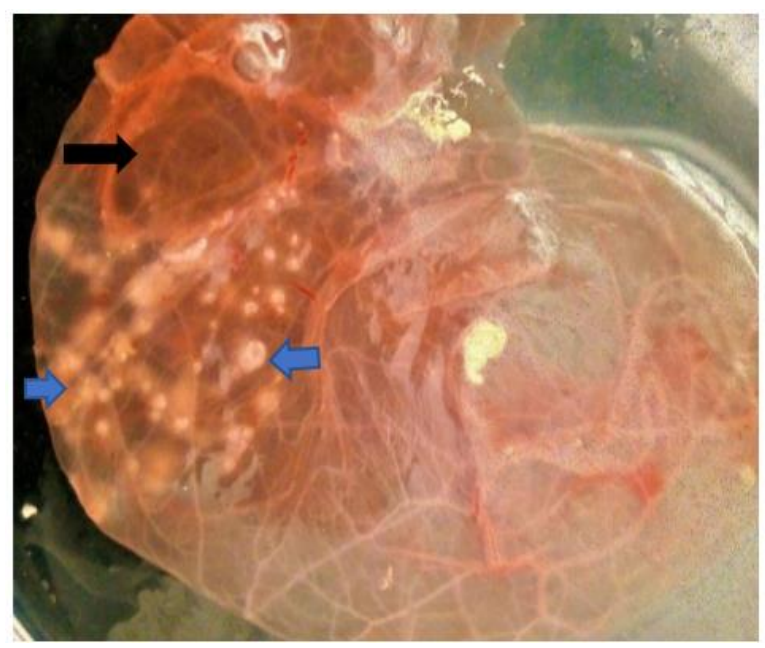

Plate II: Generalized hemorrhages (black arrow) and characteristic prominent opaque-white pock lesions (blue arrows) in chorioallantoic membrane infected with a field fowlpox virus isolate at third passages.

\section{Vaccine 'Takes' Diameter:}

At 5-days post-vaccination (dpv), group A chickens had $93.3 \%$ vaccine "takes", whereas group B chickens had $100 \%$ "takes". However, at 6 to 10-dpv, all vaccinated chickens (group A and B) showed 100\% "takes" even though some of these "takes" were very small. Overall, the highest vaccine "takes" diameter recorded per individual chicken was $13.2 \mathrm{~mm}$ on 6-dpv in group A, while the lowest was $2.7 \mathrm{~mm}$ on 10-dpv in group B. No vaccine "take" was detected in the unvaccinated chickens. From 5 to 7-dpv, group B chickens had higher mean vaccine "takes" diameters of $7.33 \pm 0.47,9.15 \pm 0.52$, and $10.74 \pm 0.41 \mathrm{~mm}$ than the corresponding group A chickens $(6.11 \pm 0.53,9.12 \pm$ 0.57 and $9.95 \pm 0.34 \mathrm{~mm}$ ) until when a peak was reached at 7-dpv, however, the differences were not statistically significant $(\mathrm{p}>0.05)$. The "takes" regressed from 8 to 10 -dpv in an inverse trend with mean values of $9.31 \pm 0.33,6.50 \pm 0.35,5.08 \pm 0.30$ for group $\mathrm{A}$, and $7.99 \pm 0.41,5.62 \pm 0.32,4.42 \pm 0.31$ for group B. However, the differences were equally not statistically significant ( $p>0.05)$ (Fig. 1).

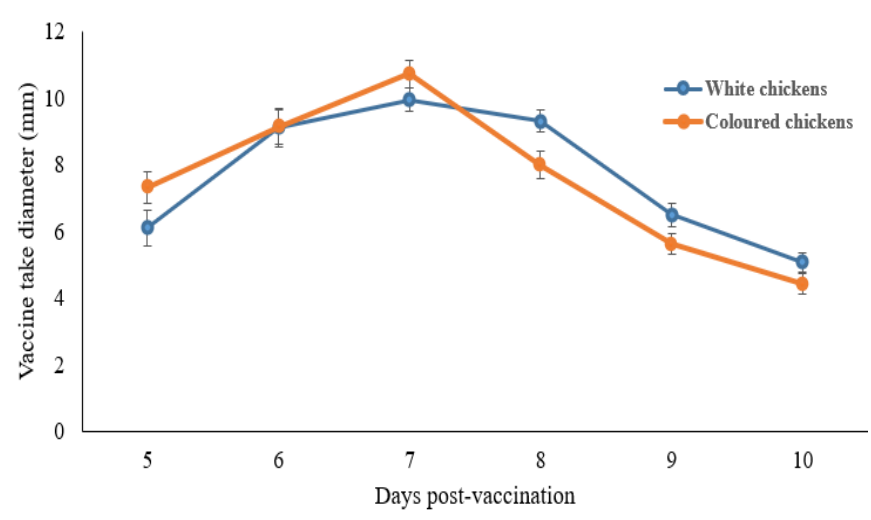

Fig.1: Mean vaccine "takes" diameters in the progeny of inbred Isa White chickens having different plumage colors vaccinated with live attenuated fowlpox virus vaccine at 8 -weeks old.

\section{Enzyme-Linked Immunosorbent Assay:}

Pre- and post-vaccination, the FWPV antibody titers in group A $(21.83 \pm 3.32 ; 41.61 \pm 6.16 \mathrm{ng} / \mathrm{L})$ were lower $(\mathrm{p}>0.05)$ compared to group B (26.89 \pm $5.47 ; 53.25 \pm 7.26 \mathrm{ng} / \mathrm{L})$. All vaccinated chickens were protected, therefore, showed no clinical sign or lesion post-challenge. Interestingly, the antibody titer level in group B, 3-weeks post-challenge was slightly lower than that recorded in $\mathrm{A}$; however, the difference was not statistically significant $(p>0.05)$ (Fig. 2). In unvaccinated-infected chickens, group D chickens had higher post-infection mean antibody titer (53.29 \pm $12.41 \mathrm{ng} / \mathrm{L})$ than group $\mathrm{C}(34.92 \pm 7.54 \mathrm{ng} / \mathrm{L})$. However, the difference was not statistically significant $(p>0.05)$ (Fig. 3).

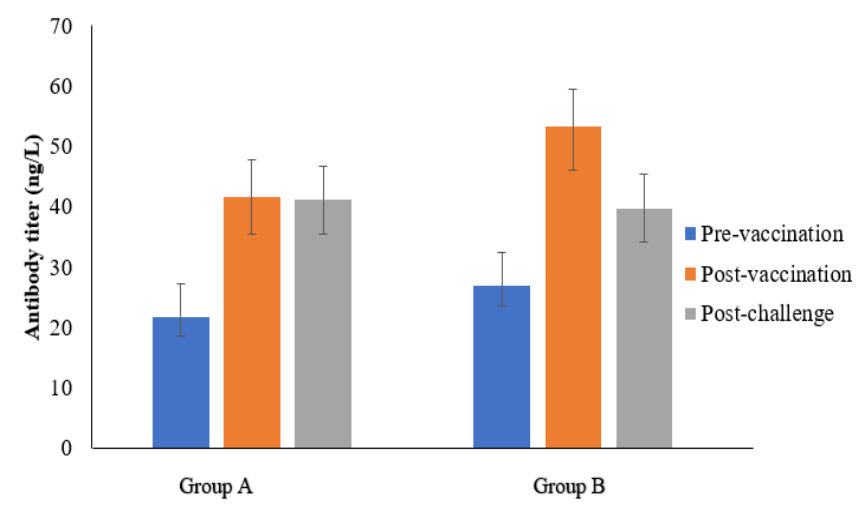

Fig. 2: Mean ( \pm SEM) fowlpox virus antibody titers in the progeny of inbred Isa White chickens vaccinated at 8-weeks old and challenged with a field fowlpox virus isolate at 11-weeks old. 


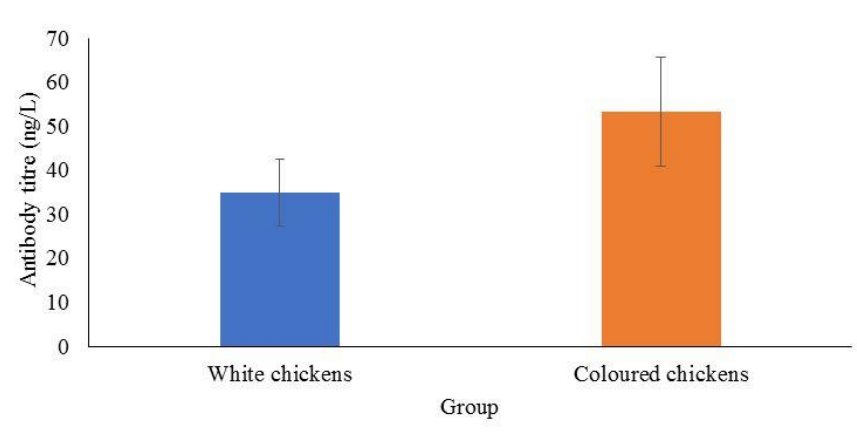

Fig. 3: Mean ( \pm SEM) fowlpox virus antibody titer in the unvaccinated progeny of inbred Isa White chickens infected with a field fowlpox virus isolate at 11-weeks old.

\section{Fowlpox Scab Lesions Count:}

All group C chickens showed classical cutaneous fowlpox lesions particularly on the featherless skin of their head, beak, eyelids and wings. In contrast, two black chickens in group D had no lesions throughout the study. The highest number of discrete fowlpox lesions per individual bird recorded was eight as seen in group $\mathrm{C}$, while the lowest was one as observed in both groups. Overall, the mean lesions count observed in group $C(4 \pm 0.562)$ chickens was significantly higher $(\mathrm{p}<0.05)$ than that of group D $(2 \pm$ 0.345) (Fig. 4).

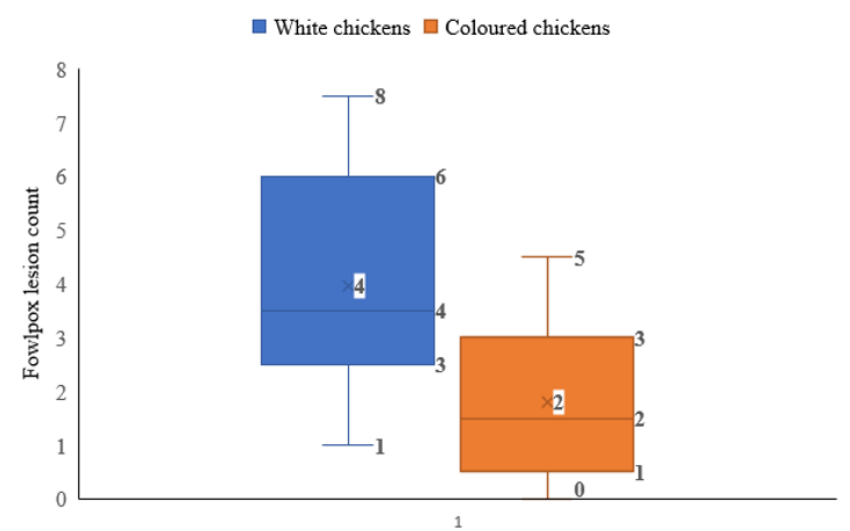

Fig. 4: Comparative fowlpox scab lesions count in the unvaccinated progeny of inbred Isa White chickens experimentally infected with a field fowlpox virus isolate at 11-weeks old.

\section{DISCUSSION}

The characteristic pock lesions observed when field FWPV isolates were propagated in CAMs of ECE in the present investigation correlate well with the findings of other research (Weli et al., 2004; Haligur et al., 2009; Khan, 2014; Masola et al., 2014) which independently reported localized pock lesions (of average size 3-6 $\mathrm{mm}$ in diameter) restricted to the dropped portion of CAMs in 9-12 days old ECE at first passage. While the enhanced cytopathology seen in CAMs during repeated passages of the field FWPV isolates signify increased ease of propagation, virulence and adaptation of the viruses in developing chicken embryos as previously reported (Gilhare $\boldsymbol{e t}$ al., 2015). Islam et al. (2008) documented that, albeit the development of pock lesions on infected CAM of ECE during FWPV propagation is a highly consistent finding, it is always unpredictable about the number of passages required for adaptation. In this study, the field FWPV isolate produced distinct pock lesions following three repeated passages. Hence, it can be a suitable candidate for developing new vaccines. High embryo mortality observed in the current trial contradicts Gilhare, (2012) who reported zero embryo mortality when isolating field FWPV. The difference might be due to variation in the virulence of field isolates involved.

The appearance of $100 \%$ vaccine "takes" in vaccinated chickens of the present study denotes a high level of protection against subsequent field challenge by virulent FWPV. This important finding correlates well with the $100 \%$ vaccine "takes" reported by Wambura and Mzula (2017) when using similar live attenuated FWPV vaccine (Biovac Vir $102^{\mathrm{TM}}$, Biovac Ltd, Israel), but differs with the 90-95\% "takes" observed by two other studies (Islam et al. 2008; ElMahdy and Mikheal, 2014). The differences observed might be most likely due to variation in FWPV vaccine strains, immune status, age and breed of the chickens used. The success of vaccination programs against FWPV is usually indicated by the presence of a protective immune response in over $80 \%$ of vaccinated chickens (OIE, 2010; Ha et al., 2013). Therefore, the presence of $100 \%$ vaccine "takes" reactions with absolute protection against pathogenic field FWPV isolate 3-weeks post-vaccination proved the potency of the FWPV vaccine used. Interestingly, vaccine "takes" might be a collection of lymphocytes (Siccardi, 1975) and possible circulating macrophage-derived immune mediators like interferons and serum nitrite; hence, consistently strong stimulation of these inflammatory reactions following FWPV vaccination as seen in chickens with white plumage implies high susceptibility with conceivable severe lesions development when exposed to a field FWPV isolate. This had vividly been underpinned by significantly higher lesion counts recorded in unvaccinated white chickens when infected with a virulent field FWPV isolate. Therefore, though the difference in the mean vaccine "takes" diameters between white and colored chickens were not statistically significant, the tide remains clinically relevant. 
The relatively higher mean ELISA antibody titers observed in colored chickens pre- and postvaccination might have been responsible for better protection against subsequent challenge with the field FWPV isolate. Conversely, the decreased FWPV antibody titer of the colored chickens at 3-weeks postchallenge could result from viral neutralization and better immunogenic response as compared to the white chickens that maintained relatively same titer despite exposure. Also, the higher antibody titer observed in the unvaccinated colored chickens posts experimental infection might imply a longer-lasting active immune response.

It is worth noting that genetically dissimilar birds have been reported to have different susceptibility rates to viral infections (Thiruvenkandan et al., 2011). For instance, it has been documented that differences in genetic background influenced the induction of innate and acquired immune responses in chicken lines, hence their susceptibility to virulent infectious bursal disease virus (vIBDV). Likewise, when genetically different chickens were challenged with vIBDV, White-leghorn chicks showed the most severe clinical disease, higher mortality rate, higher bursal lesion scores and IBDV-antigen load relative to other infected chicks (Bumstead et al., 1993; Aricibasi et al., 2009). Furthermore, interferon genes, particularly IFN- $\alpha$ and IFN- $\beta$, have been reported to confer resistance to birds against fowlpox among several other diseases (Thiruvenkandan et al., 2011; Biobaku and Ami, 2018). Therefore, chickens that do not express the above unique genes or mutations to the genes would lead to marked susceptibility to FWPV.

Moreover, the mean antibody titers recorded at different stages of this study using an indirect ELISA were relatively higher than some published data (Wang et al., 2006; Ohore et al., 2007; Stuke et al., 2017). The discrepancy could be attributed to the different FWPV vaccine strains, vaccination method, virulence of the challenge viruses, age and breeds of the birds used, and sensitivity of the detection and quantification techniques employed. The assertion that age might have influenced the relative increase in FWPV antibody titers observed is in line with other parallel studies (Siddiky et al., 2004; Wang et al., 2006; Wambura and Mzula, 2017) which established higher geometric mean titers for chickens vaccinated with live attenuated fowlpox vaccines at 6 weeks-old than those vaccinated at day-old. In addition, of the detection techniques used, ELISAs have generally been reported to detect humoral FWPV antibodies much earlier, faster and easier than the commonly employed agar gel immunodiffusion test (AGID) or passive hemagglutination test (PHA) following vaccination or infection (Buscaglia et al., 1985; Mockett et al., 1987; Pathak, 2016).
The absence of fowlpox lesions observed in the two colored (precisely black) chickens post-infection could be attributed to a possible enhanced cellmediated immune response ( $\mathrm{T}$-cell responses and cytokine gene expression) to control the fowlpox viral replication faster before the onset of lesions. This owes to the fact that cell-mediated immunity which develops earlier than the humoral immune response (Tripathy and Reed, 2020) is primarily responsible for recovery from FWPV infection (Morita, 1973; Gerlach, 1994).

\section{CONCLUSION}

Evaluation of humoral immune response, vaccine "takes" and fowlpox lesion counts provided circumstantial evidence that variation in plumage color influenced the susceptibility vis-a-vis resistance of chickens to fowlpox. This has been well demonstrated by the inferior immune response to vaccination and significantly higher fowlpox lesions post experimental infection seen in progenies of inbred Isa White chickens having white plumage. However, extensive research on genetics, cell-mediated immune responses, and other factors (such as the preference of mechanical vectors to birds) that might influence susceptibility to FWPV in chickens should be carried out.

\section{ACKNOWLEDGMENT}

The authors wish to thank Salisu Abdullahi for his assistance in sample collection and handling of the experimental animals; Drs M. Babashani for his guidance in collecting, analyzing, and interpreting data; M.T. Ahmad, O. Orakpoghenor and A.M. Tauheed for their help in reading and correcting the manuscript.

\section{Funding}

This research does not receive any specific grant from funding agencies in the public, commercial, or not-forprofit sectors.

\section{Author's contribution}

BN. Umar performed the experiments and drafted the manuscript; J. Adamu conceived, designed, and participated fully in the study; while H.M. Kazeem revised the article critically and approved its intellectual content, all authors reviewed and approved the final version of the manuscript.

\section{Declaration of Conflicting Interests}

The authors declare that there is no conflict of interest.

\section{REFERENCES}

ABDU, P.A., MERA, U.M., and SA'IDU, L., 1992. A study on chicken mortality in Zaria, Nigeria. World's Poultry Congress, Amsterdam, The Netherlands, Pp.151. 
ADENE, D.F., and FATUMBI, O., 2004. Case review and lesson on poultry disease control in southwest Nigeria, In: Poultry Health and Production, Principles and Practice, Stirling Horden Publishers (Nig) Ltd, Ibadan, Oyo State, Nigeria, Pp.191-200.

ARICIBASI, M., JUNG, A., HELLER, E.D., and RAUTENSCHLEIN, S., 2009. Differences in genetic background influence the induction of innate and acquired immune responses in chickens depending on the virulence of the infecting infectious bursal disease virus (IBDV) strain. Vet. Immunol. Immunopathol, 15 (1-2): 79-92.

BEYTUT, E., and HALIGUR, M., 2007. Pathological, immunohistochemical and electron microscopic findings in the respiratory tract and skin of chickens naturally infected with avipoxvirus. Turkish J. Vet. Anim. Sci, 31(5) 311-317.

BIOBAKU, K.T., and AMI, S.A., 2018. Predisposing factors associated with diseases in animals in Nigeria and possible botanical immunostimulants and immunomodulators: a review. Bangladesh J. Vet. Med, 16 (1): 87-101.

BUMSTEAD, N. REECE, RL., and COOK, JK., 1993. Genetic differences in susceptibility of chicken lines to infection with infectious bursal disease virus. Poultry Science, 72: 403-410.

BUSCAGLIA, C., BANKOWSKI, R. A., and MIERS, L., 1985. Cell-culture virus-neutralization test and enzyme-linked immunosorbent assay for evaluation of immunity in chickens against fowlpox. Avian Diseases, 29 (3): 672-680.

EL-MAHDY, SS., and MIKHEAL, C., 2014. Efficacy of fowlpox vaccines against isolated Egyptian strain during 2012. Vet. World, 7 (9): 656-660.

FERREIRA, B.C., ECCO, R., COUTO, R.M., COELHO, H.E., ROSSI, D.A., BELETTI, M.E., and SILVA, P.L., 2018. Outbreak of cutaneous form of avian poxvirus disease in previously pox-vaccinated commercial turkeys. Pesq. Vet. Bras, 38: 3.

GERLACH, H. 1994. Viruses. In: Avian medicine principles and applications. Winger's publishing incorporation, lake worth, Florida, Pp.865-874.

GILHARE, VR. 2012. Isolation, identification, propagation and serological study of field strain of fowlpox virus. A thesis submitted in partial fulfillment of the requirements for the degree of Master of Science, college of veterinary science and animal husbandry, Angora, Chhattisgarh kamdhenu Vishwavidyalaya, Durg, Pp 36-45.

GILHARE, V.R., HIRPURKAR, S.D., KUMAR, A., NAIK, S.K., and SAHU, T., 2015. Pock forming ability of fowlpox virus isolated from layer chicken and its adaptation in chicken embryo fibroblast cell culture. Vet. World, 8: 2231-0916.

HA, HJ, ALLEY, M., HOWE, L., and GARTRELL, B., 2013. Evaluation of the pathogenicity of avipoxvirus strains isolated from wild birds in New Zealand and the efficacy of a fowlpox vaccine in passerines. Vet. Microbiol, 165 (3-4): 268-274.

HALIGUR, M., OZMEN, O., VURAL, S.A., and BERLIN, S., 2009. Pathological, immunohistochemical and electron microscopical examinations on chorioallantoic membrane lesions in experimental fowlpox virus infection. Kafkas Univ. Vet. Fak. Derg, 15 (3): 345-350.

IDRIS, S.T., SALIH, S., BASHEIR, M., ELHADI, A., KAMEL, S., ABD-ELRAHMAN, K.A., HAMDI, A., and HASSAN, M.A., 2018. In silico Prediction of Peptide-based Vaccine against Fowlpox Virus (FPV). Immunome Research 14 (2): 1-11. doi: 10.4172/17457580.1000154

ISLAM, M.R., KHAN, M.S.R., ISLAM, M.A., KAYESH, M.E.H., KARIM, M.R., GANI. MO., and KABIR, A., 2008. Comparative efficacy of imported fowlpox virus vaccine with locally produced one in backyard chicks. Bangladesh J. Vet. Med, 6 (1): 23-26.

KHAN, FF., 2014. Studies on field strain of pigeon pox virus and its Comparison with field and vaccine strains of fowlpox virus. A Thesis Submitted in Partial Fulfilment of the Requirements for the Degree of Master of Science, College of Veterinary Science and Animal Husbandry, Anjora, Chhattisgarh kamdhenu Vishwavidyalaya, Durg, Pp. 22-67.

MACLACHLAN, NJ., and DUBOVI, EJ., 2017. Fowlpox. In: Fenner's Veterinary Virology $\left(5^{\text {th }}\right.$ ed.) Elsevier Academic Press, Amsterdam. Pp. 157-174.

MASOLA, S.N., MZULA, A., TUNTUFYE, H.N., KASANGA, C.J., and WAMBURA, P.N., 2014. Isolation and molecular biological characterization of fowlpox virus from specimen of cutaneous nodular lesions from chickens in several regions of Tanzania. Br. Microbiol Res. J, 4:759-771.

MESEKO, A.C., ADEMOLA, S.I., and OLUWASEUN, A., 2012. Seroprevalence of fowl pox antibody in indigenous chickens in Jos North and South council areas of Plateau State, Nigeria: Implication for Vector Vaccine. ISRN Vet. Sci. doi: 10.5402/2012/154971.

MOCKETT, APA, SOUTHEE, DJ, TOMLEY, FM., and DEUTER, A., 1987. Fowlpox virus: Its structural proteins and immunogens and the detection of viral-specific antibodies by ELISA. Avian Pathology, 16 (3): 493-504

MORITA, C. 1973. Role of humoral and cell-mediated immunity on the recovery of chickens from fowlpox virus infection. J. Immunol, 111:1495-1501.

ODOYA, E.M., ABEGUNDE, A., AGYOGBO, B.G., OMOTAINSE, S.O., GWANKAT, E., and OKPARA, U.G., 2006. Outbreak of turkeypox disease in fowlpox vaccinated poults in Vom Plateau State of Nigeria. African J. Clin. Exp. Microbiol, 7: 136-138.

OHORE, O.G., EMIKPE, B.O., OLUWAYELU, D.O., ADEYEMI, R.O., and OCKIYA, M.A., 2007. Seroprofiling of antibodies to fowlpox in commercial and indigenous chickens in Southwestern Nigeria. J. Anim. Vet. Adv, 6 (5): 697-701.

OIE., (Office Internationales Epizooties terrestrial manual). 2016. Fowlpox Ch. 3.2.10. Retrieved at 11:30 am on 10th march, 2018 from www.oie.int/fileadmin/Home/eng/Health_ standards/ tahm/2.03.10_fowlpox.

OIE (Office Internationales Epizooties). 2010. Manual of diagnostic tests and vaccines for terrestrial animals. Retrieved at 02:20 pm on 14th March 2018 from http://www.oie.int/internationalstandard-setting/terrestrial manual/access-online. 
OKWOR, E.C., EZE, D.C., and CHAH, K.F., 2014. Recurring outbreaks of fowlpox in a poultry farm in Nsukka, Southeast Nigeria, IOSR J. Agri. Vet. Sci, 7 (4): 104-108.

PATHAK, N. 2016. Prevalence, pathology and molecular diagnosis of pox in domestic birds. A thesis submitted in partial fulfillment of the requirements for the degree of Doctor of Philosophy in Veterinary Pathology, Assam Agricultural University, Khanapara, Guwahati, Pp. 91-92.

SARMA, G., KERSTING, BA., and SPINA, G., 2019. Field safety and efficacy of a unique live virus vaccine for controlling avian encephalomyelitis and fowlpox in poultry. Vet. World, 12 (8): 1291-1298.

SICCARDI, FJ., 1975. The addition of fowlpox and pigeon pox vaccine to Marek's vaccine for broilers. Avian Diseases, 19 (2): 362-365.

SIDDIKY, MNA, AMIN, MM., and KHAN, MSR., 2004. Efficacy of experimentally developed pigeon pox vaccine against fowlpox. Bangladesh Vet. J, 21 (2): 92-96.

SRINIVASAN, V., SCHNITZLEIN, W.M., and TRIPATHY, D.N., 2001. Fowlpox virus encodes a novel DNA repair enzyme, CPD-photolyase that restores infectivity of UV light-damaged virus. Virology, 75: 1681-1688.

STUKE, K., ERASMUS, H.L., SWANEPOEL, S., and SALT, J., 2017. Immune response in chickens to fowlpox virus vaccine and Newcastle disease vaccine co-administered by non-invasive route. GALVmed Epizone poster 1. Retrieved from tps://assets.publishing.service.gov.uk/media/5aa7fc12 $40 f 0 b 66 \mathrm{~b} 625 \mathrm{e} 2 \mathrm{~b} 41$.

THIRUVENKANDAN, A.K, PRABAKARAN, R., and PANNEERSELVAM, S., 2011. Broilers breeding strategies over decades: An Overview. World Poult. Sci. J, 67: 309-336.

TRIPATHY, D. N., and REED, WM., 2020. Pox. In: Swayne, D.E. (Ed). Diseases of Poultry. $13^{\text {th }}$ edition. John Wiley \& Sons, Inc, Pp. 364-381.

TRIPATHY, DN., and REED, WM., 2008. Pox. In: A laboratory manual for the isolation, identification and characterization of avian pathogens. American Association of Avian Pathologists press, Athens, Pp.116-119.

VANRIPER, C., and FORRESTOR, D.J., 2007. Avian pox. In: Thomas, N.B., Hunter D.B. and Atkinson, C.T. (Ed) Infectious Diseases of Wild Birds, IA Blackwell Publishing, Ames, Iowa, USA, pp. 131176.

WAMBURA, P., and MZULA, A., 2017. A novel rapid direct haemagglutination-inhibition assay for measurements of humoral immune response against non-haemagglutinating Fowlpox virus strains in vaccinated chickens. Heliyon, 3: 10.

WANG, J., MEERS, J., SPRADBROW, P.B., and ROBINSON, W.F., 2006. Evaluation of immune effects of fowlpox vaccine strains and field isolates. Vet. Microbiol, 116:106-119.

WELI, S.C., OKEKE, M.I.O., TRYLAND, M., NILSSEN, O., and TRAAVIK, T., 2004. Characterization of avipoxviruses from wild birds in Norway. Can. J. Vet. Res, 68:140-145.
How to cite this article:

Bala Ningi Umar, Jibril Adamu, and Haruna Makonjuola Kazeem, 2021. Plumage Color Influence on Immune Response and Severity of Fowlpox in The Progeny of Inbred Isa White Chickens. Journal of Applied Veterinary Sciences, 6 (4): $51-57$.

DOI:https://dx.doi.org/10.21608/javs.2021.88574.1097 